\title{
A hitelértékelési kiigazítás tőketartalékolásának új szabályozása
}

\begin{abstract}
A hitelértékelési kiigazításból (credit valuation adjustment, CVA) adódó veszteségek elleni tőketartalékolás szabályozása jelentős reformon megy keresztül. Az új szabályozásban a jelenleg hatályos standardizált módszert egy új, hivatalos nevén alap-CVA-formula váltja fel. Tanulmányunkban ezt a módszert ismertetjük és elemezzük. Bemutatjuk a szabályozói egyenlet mögött meghúzódó modellt, és kiemeljük a Bázel-III. szabályozástól vett eltéréseket. Az új előírás által adott tőkeszükségletet numerikus példákon keresztül hasonlítjuk a modell eredményeihez. Rámutatunk, hogy a javaslat jellemzően konzervatívabb tőketartalékolást vár el, mint elödje. Továbbá bemutatjuk, hogy a tökéletesen fedezett portfólió és a nulla tőkeszükségletủ portfólió továbbra is eltér egymástól.*

Journal of Economic Literature (JEL) kód: C15, C53, G12, G13, G32, G33.
\end{abstract}

\section{Bevezetés}

A hitelértékelési kiigazítás (credit valuation adjustment, CVA) szakirodalmában az egyik legtöbbet idézett mondat a Bázeli Bankfelügyeleti Bizottságtól származik: „A globális pénzügyi válság során a partnerkockázathoz kapcsolódó veszteségek közel kétharmada a hitelértékelési kiigazítás értékének megváltozásából adódott, és csupán egyharmaduk volt tényleges csődeseményeknek betudható.”1

A mondat jól illusztrálja a hitelértékelési kiigazítás relevanciáját, ezt szokás idézni a CVA számítását elemző munkákban. Erre az idézetre támaszkodik az a gyakori érvelés is, hogy a CVA pontos meghatározása a hozzá kapcsolódó veszteségek miatt különös fontosságú, eredetileg a Bázel-III. szabályozói keretrendszer publikálásakor

\footnotetext{
* A tanulmányban kifejtett nézetek kizárólag a szerző személyes véleményét tükrözik.

1 "During the global financial crisis, however, roughly two-thirds of losses attributed to counterparty credit risk were due to CVA losses and only about one-third were due to actual defaults." http:// www.bis.org/press/p110601.htm.
}

Boros Péter PhD-hallgató, Budapesti Corvinus Egyetem, Befektetések és Vállalati Pénzügy Tanszék (e-mail: borospeter90@gmail.com).

A kézirat első változata 2017. július 28-án érkezett szerkesztőségünkbe.

DOI: http://dx.doi.org/10.18414/KSZ.2018.2.161 
a Bázeli Bankfelügyeleti Bizottság ezzel indokolta a CVA változásából adódó veszteségek elleni szabályozói tőkeszükséglet bevezetését.

A CVA szerinti tőkeképzés mára már általánosan elfogadott eljárássá vált. A jelenleg hatályban lévő rendszer szerint egy fejlett és egy standard formula alapján kell tőkét képezni. ${ }^{2}$ A Bázeli Bankfelügyeleti Bizottság 2015 júliusában azonban kiadott egy tervezetet a jövőbeli CVA-tőkeképzés keretéről. A BCBS [2015] javaslata annak ellenére, hogy számos ponton kiegészíti, valamint javítja elödjét, mégsem aratott felhötlen sikert. A válság óta óriási tőkebevonáson átesett és gyakran már túlszabályozottnak kikiáltott bankrendszer érthetően nagy óvatossággal fogadja a tőkeszükségleteket érintő új szabályokat. Így nem meglepő például az ISDA vezetőinek levelét olvasni, amelyben az új módszert kritizálva többek között az alábbi követelményeket fogalmazták meg: ${ }^{3}$

- a szabályozói CVA számviteli társával történő jobb összeegyeztetése,

- a fedezeti ügyletek és további árkiigazítások figyelembevétele a tőkeszükséglet szabályozásában,

- az alap CVA-módszer (basic, BA-CVA) kockázati súlyainak és paramétereinek újrakalibrálása és hitelkockázati érzékenységük javítása,

- további, a belső modellen alapuló számítás teljesítményének teszteléséhez kapcsolódó magyarázat és a modellkockázati paraméter újrakalibrálása.

Az új CVA-tőkeszabályozás körülötti feszültségeket a Bázeli Bankfelügyeleti Bizottság újabb lépéseivel csak tovább fütötte. 2016 februárjában egy valamelyest átdolgozott szabályozás hatásait szerették volna vizsgálni a bizottság standard kvantitatív hatásvizsgálatának (Quantitative Impact Study, QIS) keretében. A QIS során három módszer állt rendelkezésre: egy belső modellezésen alapuló fejlett módszer (internal model-based approach, CVA-IMA), egy érzékenységen alapuló, standardizált formula (standardised approach, SA-CVA), valamint egy, a kisbankoknak célzott alap- (standardizált) megközelítés. Egy hónappal később egy új közleményben váratlanul eltörölték a CVA-IMA fejlett módszert, arra hivatkozva, hogy az új kötelezö kétoldalú letéti szabályozás és a központi klíring csökkenti a CVA-kockázatot, így nincs szükség bonyolult belső modellezésen alapuló szabályozásra (BCBS [2016b]). A döntés iparági fogadtatása ismét negatív volt, hiszen a standardizált súlyok sokkal konzervatívabbak, mint a kockázatra ténylegesen érzékeny belső modell alapján történő megközelítés. Voltak, akik kiemelték, hogy a Bázeli Bankfelügyeleti Bizottság által hozott érv valójában nem mérvadó, hiszen a portfóliójuk jelentős részét nem érinti a kétoldalú kötelező letéti szabályozás (Wood [2016]). Érdekes módon a kvantitatív hatásvizsgálathoz kiadott $B C B S$ [2016c] dokumentumban továbbra is azt kérték, hogy a résztvevők a CVA-IMA módszerhez tartozó részeket is töltsék ki.

Jelen pillanatban két megközelítés maradt a szabályozók eszköztárában: az érzékenységen alapuló SA-CVA és az alap BA-CVA megközelítés. Feltételezhető, hogy az

\footnotetext{
${ }^{2}$ A jelenlegi Bázel-III. néven emlegetett szabályozást a $B C B S$ [2011] dokumentuma részletezi.

${ }^{3}$ A nemzetközi csere- és származtatott ügyletek szövetségének (International Swaps and Derivative Association, ISDA) levele elérhető az alábbi linken: http://www.bis.org/bcbs/publ/comments/ d325/igijr.pdf.
} 
érzékenységen alapuló módszer a kereskedési könyv várható új szabályozása miatt, ${ }^{4}$ az alap CVA-módszer pedig a kevésbé fejlett bankok korlátai miatt része lesz a BCBS végső javaslatának (Sherif [2016]). Jelen munka tárgya az alap CVA-módszer.

A bázeli javaslat az alap CVA-módszerre „a standard módszer javított verziójaként" hivatkozik. Valójában az új alap CVA-módszer mögött a korábbi standardizált módszer húzódik meg. Pykhtin [2012] munkája egy általános modellkeretet ad meg, amelyből a standard módszerhez tartozó szabályozói formulák származtathatók. Ebben a tanulmányban elsőként bemutatjuk az új módszert, és megvizsgáljuk, hogy pontosan mely pontokon is javított elödjén. Ezután Pykhtin [2012] módszertanából kiindulva, majd kiegészítve azt, rámutatunk, hogy pontosan milyen analitikus modell is áll az alap CVA-formula mögött. Végül numerikus próbákon vizsgáljuk a két módszert, és néhány példán keresztül kiemelünk számos fontos eredményt.

Rámutatunk, hogy az új alap CVA-szabályozás bizonyos helyzetekben konzervatívabbnak tekinthető elődjénél, és az eltérés szintjét a korrelációs paraméter függvényében elemezzük. Továbbá kiemelten vizsgáljuk a fedezeti ügyletek szerepét. Ugyan az új szabályozás közelebb hozza a tökéletesen fedezett portfóliót a nulla tőkeszükségletü portfólióhoz, azonban ezek még mindig nem esnek egybe. Ebből adódóan viszont bizonyos helyzetekben az alap CVA-módszer kisebb tőkeszükségletet ad eredményül, mint azt a kiinduló modell tenné.

A tanulmány felépítése a következő: bemutatjuk a bázeli CVA-tőkeszükséglet alapfogalmait, majd ismertetjük az alap CVA-módszert. Ezután Pykhtin [2012] munkáját felhasználva megmutatjuk, hogy egy egyszerü faktormodellből kiindulva, hogyan is juthatunk el a szabályozói formuláig. Majd numerikus teszteket futtatva hipotetikus portfóliókon, megvizsgáljuk a formula viselkedését és az alapmodelltől való eltérésének okait. Az utolsó részben összefoglaljuk a tapasztalatokat.

\section{Tőketartalékolás az alap CVA-módszer szerint}

A tőkeszükséglet új CVA-számításának bemutatása előtt rövid bevezetést adunk a partnerkockázati tőketartalékolás legfontosabb fogalmaiba. Először a partnerkockázat-kezelés során használt kitettség fogalmát vezetjük be. ${ }^{5}$ Tegyük fel, hogy $B$ és $C$ megköt egy $T$-edik időpontban lejáró derivatív szerződést. Ha rövid időre feltételezzük, hogy $B$ és $C$ partnerkockázat-mentesek, azaz sohasem csődölhetnek be, akkor jelölje $\Pi(t, T)$ az általuk kötött derivatív ügylet $t$ és $T$ közötti diszkontált pénzáramainak az összegét $B$ szemszögéböl. Nevezzük ezt kockázatmentes diszkontált nettó pénzáramnak. A kockázatmentes diszkontált nettó pénzáram alapján a következőképpen definiálhatjuk a derivatív ügylet $t$-ben vett árát:

$V(t)=\mathbb{E}_{t}[\Pi(t, T)]$,

\footnotetext{
${ }^{4}$ A javaslatot gyakran FRTB néven szokás említeni az angol címe alapján: Fundamental Review of the Trading Book (BCBS [2016a]).

${ }^{5}$ Brigo és szerzőtársai [2013] nagyszerü összefoglalást ad a partnerkockázat alapfogalmairól.
} 
ahol $\mathbb{E}_{t}[]=.\mathbb{E}_{t}\left[. \mid \mathcal{F}_{t}\right]$ azaz az $\mathcal{F}_{t}$ filtrációra vett, kockázatsemleges mérték szerinti feltételes várható érték.

Most vezessük be a partnerkockázatot a modellbe azzal a feltételezéssel, hogy mindkét fél a derivatíva élettartama során fizetésképtelenné válhat. Csőd esetén a derivatív szerződést azonnal zárják, ekkor a túlélő fél köteles minden tartozását megfizetni a fizetésképtelen partnernek, míg követelésein veszteséget fog elszenvedni. A veszteség a fizetésképtelen partnertől visszaszerezhető értéken múlik, a visszaszerezhető érték arányát rendszerint $R E C_{i}$-vel jelölik, ahol $i \in\{B, C\}$ és $0 \leq R E C_{i} \leq 1$. A tanulmányban a megtérülés helyett a veszteséget fogjuk használni, azaz gyakran az $L G D_{i}=1-R E C_{i}$ jelölést vezetjük be.

Így amikor partnerkockázatról beszélünk, leggyakrabban csak a partnerünk által fennálló tartozás mértékére vagyunk kíváncsiak, hiszen alternatív esetben nem veszítünk az ügylet értékén. Ez a kitettség fogalmának az alapja:

$E(t)=\max \{0, V(t)\}$.

Tehát a $t$-edik időpontban fennálló kitettség a derivatíva piaci értékének pozitív része. Ezt felhasználva definiálhatjuk a várható pozitív kitettség profilját:

$E E(t)=\mathbb{E}_{0}[E(t)]=\mathbb{E}_{0}\left[\left(\mathbb{E}_{t}[\Pi(t, T)]\right)^{+}\right]$,

ahol $(x)^{+}=\max \{0, x\}$. A számítás céljától függően a külső $\mathbb{E}_{0}$ várható érték ebben az esetben jelentheti a kockázatsemleges és a valós mérték alatt vett várható értéket is. Így például partnerlimitek meghatározásához a valós mérték alatt, míg a hitelértékelési kiigazítás számításakor a kockázatsemleges mérték alatt kell számolni. Most már megadhatjuk az így kapott profil lejáratig vett integráljának az átlagát, amelyet szokás hitel-egyenértékesnek is hívni.

$E P E=\frac{1}{T} \int_{0}^{T} E E(t) d t$.

A gyakorlatban szokás egy $0=T_{0}<T_{1}<T_{2}<\ldots<T_{m-1}<T_{m}=T$ felosztást használni és az $E P E$-t a következőképpen közelíteni:

$E P E=\frac{1}{T} \sum_{i=1}^{m} E E\left(T_{i}\right)\left(T_{i}-T_{i-1}\right)$.

A szabályozói tőketartalékolásban felhasznált nemteljesítéskori kitettséghez az első évhez tartozó, nemcsökkenő $E E(t)$ profilt kell használni, így kapjuk az effektív várható pozitív kitettség fogalmát:

$E E P E=\sum_{i=1}^{m^{\prime}} \max _{j \leq i}\left\{E E\left(T_{j}\right)\right\}\left(T_{i}-T_{i-1}\right)$,

ahol $T_{m^{\prime}}=1$. A bázeli szabályok tőkeszükséglet-képletének egyik fontos bemeneti paramétere a nemteljesítéskori kitettség $(E A D)$, amely a fentiek alapján a következő formában áll elö: 
$E A D=\alpha E E P E$,

ahol $\alpha$ egy szabályozói paraméter, jellemzően $\alpha=1,4$. A kitettségi profilok alapján a lejáratot is átsúlyozhatjuk, így eljutva az effektív lejárat fogalmához:

$M_{\text {eff }}=1+\frac{\sum_{k>m^{\prime}}^{m} E E\left(T_{i}\right)\left(T_{i}-T_{i-1}\right) D F\left(T_{i}\right)}{\sum_{i=1}^{m^{\prime}} \max _{j \leq i}\left\{E E\left(T_{j}\right)\right\}\left(T_{i}-T_{i-1}\right) D F\left(T_{i}\right)}$,

ahol $D F($.) jelöli a diszkontfaktort.

Végül definiáljuk a hitelértékelési kiigazítást! A bázeli szabályok az egyoldalú hitelértékelési kiigazítást fogadják el, amely szerint a kiigazítást számító fél csődkockázatát figyelmen kívül kell hagyni. A fentiek alapján a hitelértékelési kiigazítást az alábbi komplex formában definiálhatjuk, amit célszerủ rögtön egy jobban áttekinthetö alakra egyszerüsíteni:

$$
\begin{aligned}
C V A & =\mathbb{E}_{0}\left[L G D 1_{(t<\tau \leq T)} D F(\tau)\left(\mathbb{E}_{\tau}[\Pi(\tau, T)]\right)^{+}\right] \approx \\
& \approx \sum_{i=1}^{m} \mathbb{E}_{0}\left[L G D 1_{\left(T_{i-1} \leq \tau<T_{i}\right)} D F\left(T_{i}\right)\left[V\left(T_{i}\right)\right]^{+}\right]= \\
& =\sum_{i=1}^{m} L G D \mathbb{E}_{0}\left[1_{\left(T_{i-1} \leq \tau<T_{i}\right)}\right] \mathbb{E}_{0}\left[D F\left(T_{i}\right)\left[V\left(T_{i}\right)\right]^{+}\right]= \\
& =\sum_{i=1}^{m} L G D \mathbb{Q}\left(T_{i-1}<\tau \leq T_{i}\right) E E^{*}\left(T_{i}\right),
\end{aligned}
$$

ahol első lépésként a fent megadott $0=T_{0}<T_{1}<T_{2}<\ldots<T_{m-1}<T_{m}=T$ időfelosztáson közelítettük a számítást, majd feltételeztük a csődesemény és kitettség függetlenségét. Végül bevezettük a kockázatmentes csődvalószínüség $\left[\mathbb{Q}\left(T_{i-1} \leq \tau<T_{i}\right)\right]$ és a diszkontált kitettségi profil $\left[E E^{*}\left(T_{i}\right)\right]$ jelöléseket. Az így kapott mennyiségre szokás számviteli CVA-ként hivatkozni, hiszen ez a tényező a kockázatmentes árat csökkenti.

A Bázeli Bankfelügyeleti Bizottság (BCBS [2015]) javaslata alapján az új standardizált, hivatalos nevén alap CVA-tőkeszámítási módszert választó intézményeknek az alábbi formula szerint kell tőkét képezniük a hitelértékelési kiigazítás mozgásából adódó veszteségekre:

$K=K_{\text {spread }}+K_{E E}$

ahol $K$ jelenti a szabályozói tőke nagyságát és

$$
\begin{aligned}
K_{\text {spread }} & =\left\{\left[\rho \sum_{c}\left(S_{c}-\sum_{h} r_{h c} S_{h}^{S N}\right)-\sum_{i} S_{i}^{\text {ind }}\right]^{2}+\right. \\
& \left.+\left(1-\rho^{2}\right) \sum_{c}\left(S_{c}-\sum_{h} r_{h c} S_{h}^{S N}\right)^{2}+\sum_{c} \sum_{h}\left(1-r_{h c}^{2}\right)\left(S_{h}^{S N}\right)^{2}\right\}^{\frac{1}{2}},
\end{aligned}
$$


valamint

$K_{E E}=0,5\left[\left(\rho \sum_{c} S_{c}\right)^{2}+\left(1-\rho^{2}\right) \sum_{c} S_{c}^{2}\right]^{\frac{1}{2}}$.

A szabályozói tőkeszükséglet tehát két tagból tevődik össze. Ahogy azt hamarosan megmutatjuk, az első tag $\left(K_{\text {spread }}\right)$ a partnerek hitelfelárának elmozdulásából adódó veszteség ellen tőkésít. A második tagnak $\left(K_{E E}\right)$ számszerüsítenie kellene az egyoldalú hitelértékelési kiigazítás másik fontos inputjának, a kitettségi profilok megváltozásának hatását, azonban sokkal közelebb áll az első taghoz.

A formulák megértéséhez vegyük végig az egyenletben szereplő egyes tagokat! A partnereket $c$, a fedezeteket (hedge-eket) $h$ és az indexfedezeteket $i$ indexek jelölik. Az $S_{c}$ a $c$ partnerrel szemben fennálló kitettség nagyságát számszerüsíti az alábbi formában:

$S_{c}=\frac{R W_{b(c)}}{\alpha} \sum_{n s \in c} M_{n s} E A D_{n s}$,

ahol $M_{n s}$ és $E A D_{n s}$ a $c$ partnerhez tartozó $n s$ nettósítási csoporthoz rendelt effektív lejárati és nemteljesítéskori kitettség. Egy nettósítási csoport a partnerrel kötött olyan ügyletek összessége, amelyeknek az egymással történő nettósítása engedélyezett. A tanulmányban az egyszerüség kedvéért partnerenként egy ügyletet tételezünk fel. Így nincs szükség a nettósítási csoport definíciójára, de az általunk leírt eredmények ugyanúgy igazak több ügylet esetén is. Végül az $R W$ egy a szabályozó által elöírt súly, amelyet hamarosan ismertetünk, és az $\alpha$ a már korábban bevezetett szabályozói paraméter.

A kitettséget és így a tőkeszükségletet két típusú lehetséges fedezeti eszközzel csökkenthetjük: egy referencianévre szóló hitelmulasztási ügylettel (CDS) vagy indexfedezet segítségével. A $h$ vállalatra szóló hitelmulasztási csereügylet által kínált védelem $S_{h}$ formában jelenik meg, ahol:

$S_{h}^{S N}=R W_{b(h)} M_{h}^{S N} B_{h}^{S N}$.

A (14) formulában $M_{h}^{S N}$ jelenti a CDS lejáratát és $B_{h}^{S N}$ a diszkontált névértékét, azaz

$B_{h}^{S N}=B \frac{1-e^{-0,05 M_{h}^{S N}}}{0,05 M_{h}^{S N}}$,

ahol $B$ a CDS névértéke. A hitelindexekre vásárolt fedezet a (14) egyenlethez teljesen hasonló formában írható fel, azzal a különbséggel, hogy a lejárat és a névérték paraméterei a CDS-indexre vonatkoznak. A tanulmányban eltekintünk az ilyen típusú fedezeti ügyletektől, azaz a (11) egyenletben $S_{i}^{\text {ind }}=0$ választással élünk.

A $\rho$ és $r_{h c}$ szabályozói korrelációs paraméterek, amelyek értékét az 1. táblázatban közöljük. Ennél a pontnál már világosan látszik, hogy $K_{E E}=0,5 K_{\text {spread }}$, feltéve, hogy nem használunk fedezeti ügyleteket. 
1. táblázat

Korrelációs paraméterek

\begin{tabular}{llc}
\hline Paraméter & A fedezet és a partner kapcsolata & A paraméter értéke (százalék) \\
\hline$r_{h c}$ & $\begin{array}{l}\text { A partnerre vásárolt fedezet esetén } \\
\text { A fedezet egy másik félre szól, de annak jogi } \\
\text { kapcsolata van a partnerrel }\end{array}$ & 80 \\
& $\begin{array}{l}\text { A fedezet egy másik félre szól, de az eredeti partnerrel } \\
\text { megegyezó szektorban és régióban tevékenykedik }\end{array}$ & 50 \\
$\rho$ & & 50
\end{tabular}

A formula ugyan hasonló a jelenleg hatályban lévő standardizált képlethez, azonban sok tekintetben különbözik attól. A bázeli javaslat is „a standard módszer javított verziójaként" hivatkozik az alap CVA-formulára. ${ }^{6}$ A legszembetűnőbb változás, hogy a hitelfelárak mozgásából adódó változások mellett már a kitettség értékének megváltozására is tőkét $\left(K_{E E}\right)$ kell képezni. A kitettség mozgásából adódó veszteség eddig figyelmen kívül hagyott tényező volt, így az új CVA-formula valóban javíthatott volna az elődjén, ha a kitettség változását megfelelően tőkésítik. Valójában azonban egy, a kitettségi profil tényleges változására egyáltalán nem érzékeny, konzervatív érték szerepel a javaslatban.

A második legfontosabb eltérés, hogy a figyelembe vehető fedezeti ügyletek halmaza bővült. Szemben a korábbi gyakorlattal, amely szerint csak a partnerre szóló hitelmulasztási ügyletek az elfogadottak, most a partnerrel egy szektorban és régióban tevékenykedő vállalatokra szóló, proxy fedezetek is beszámíthatók a tőkeszámításba. Az ezekből származó előny értelemszerüen büntetve, az $r_{h c}$ faktoron keresztül jelenik meg a formulában. A $K_{E E}$ formula jellegéből adódóan a kitettségi profil mozgását fedező tranzakciók továbbra sem járulnak hozzá a CVAtőkeszükséglet csökkentéséhez.

Továbbá a (13) egyenletben az $\alpha$ faktorral osztott $E A D$ jelenik meg, ami jelentös lépés a szabályozói és a számviteli CVA-összehangolása felé. Ennek a fedezés szempontjából különös a szerepe, hiszen a korábbi keretrendszer mellett a tőketartalékot képző felek, ha a szabályozói tőkeszükségletük szerint fedezték a hitelértékelési kiigazítást, akkor nagyobb veszteséget generálhattak maguknak, mert a két módszer nem volt összehangolva. Carver [2013] alapján láthatjuk, hogy nem csupán elméleti problémáról van szó, hiszen a Deutsche Bank tőkeszükségleteinek csökkentése miatt volt kénytelen elszenvedni egy 94 millió eurós veszteséget. Ahogy hamarosan megmutatjuk, az új módszer javítása nem oldja meg teljesen ezt a problémát.

Az új CVA-tőketartalékolási keretrendszer egyik célja, hogy a mostanában gyakran előtérbe kerülő - a kereskedési könyv átfogó reformjának nevezett - új szabályozással összhangban álló módszertant teremtsen (BCBS [2016a]). A reform ugyan számos téren jelentős újításokat vezet be, de talán az egyik leggyakrabban

\footnotetext{
6 "The Basic CVA framework consists of a single Basic CVA approach (BA-CVA) that is essentially an improved version of the current Standardised CVA method." (BCBS [2015])
} 
emlegetett változás a kockáztatott érték $(\mathrm{VaR})$ cseréje a VaR-on túli várható veszteség (expected shortfall, ES) kockázati mértékére. Ezzel összhangban a CVA-töke is egy várhatóveszteség-alapú mutató eredménye lesz, amelynek szignifikanciaszintjét 97,5 százalékos értéknél határozták meg.

Végül, a standardizált $R W$ paramétereket is újrakalibrálták. Így már nem közvetlenül a partner hitelminősítési osztálya adja meg a formulában használandó súlyt, hanem egy kettős, a befektetési minősítésen és a partner tevékenységét leíró szektoron alapuló hozzárendelés dönti el annak nagyságát. A formula egyes elemeinek megismerése után a következőkben a szabályozói formula mögött meghúzódó modell levezetésével foglalkozunk.

\section{Az alapformula modellkerete}

A (11) egyenletben szereplő kifejezések valójában egy egyszerü modellből kapott veszteségek, a szabályozók által megadott szignifikanciaszint melletti kockázati mértékei. Az új CVA-tőkeszabályozás alapjai a jelenleg hatályban lévő standard szabály mögött meghúzódó modellen nyugszanak, amelyet Pykhtin [2012] vázolt fel részletesen. Ebben a részben ezért erősen támaszkodunk Pykhtin [2012] munkájára, és néhány ponton kiegészítjük azt, hogy végül az új szabályozás mögötti modellkerethez jussunk el. Az új tőkeszükséglet-szabályozás továbbra is csak az egyoldalú hitelértékelési kiigazítást használja, amely az árat számoló felet kockázatmentesnek tekinti. Elöször szükségünk van a (9) egyenletben használt csődvalószínüségek formalizálására. Ehhez használhatunk egy egyszerü redukált formájú modellt, ahol

$\mathbb{Q}(\tau>t)=e^{-h t}$,

ahol $h$ a $\tau$ csődidőponthoz tartozó intenzitás vagy kockázati arány. Az olvasó a redukált formájú csődmodellekről a Brigo és szerzötársai [2013] könyvben talál részletes leírást. Tegyük fel, hogy az $i$-edik partnerrel kötött derivatívák közül a leghosszabb lejárata $T$. Ekkor a $0=t_{0}^{i}<t_{1}^{i}<\ldots<t_{N}^{i}=T^{i}$ közelítéssel a partnerhez tartozó egyoldalú hitelértékelési kiigazítást az alábbi formában számolhatjuk:

$$
\begin{aligned}
C V A & =\sum_{k=1}^{N} L G D \mathbb{Q}\left(t_{k-1}^{i}<\tau \leq t_{k}^{i}\right) E E^{*}\left(t_{k}^{i}\right)=\sum_{k=1}^{N} L G D\left(e^{-h_{i} t_{k-1}^{i}}-e^{-h_{i} t_{k}^{i}}\right) E E^{*}\left(t_{k}^{i}\right)= \\
& =\sum_{k=1}^{N} L G D\left(e^{-h_{i} t_{k}^{i}} e^{-h_{i}\left(t_{k-1}^{i}-t_{k}^{i}\right)}-e^{-h_{i} i_{k}}\right) E E^{*}\left(t_{k}\right)= \\
& =\sum_{k=1}^{N} L G D\left(e^{-h_{i} t_{k}^{i}}\right)\left(e^{h_{i}\left(\Delta t_{k}^{i}\right)}-1\right) E E^{*}\left(t_{k}^{i}\right) .
\end{aligned}
$$

A fenti egyenletet Pykhtin [2012] az egyenlet elsőrendủ Taylor-közelítésével helyettesíti, és ezt a mennyiséget tekinti a tőketartalékolási szabály alapjának. Ha felhasználjuk, hogy $s_{i} / L G D_{i} \approx h_{i}$, ahol $s_{i}$ a partner hitelfelára, akkor az egyszerüsített hitelértékelési kiigazítást az alábbi formában adhatjuk meg: 
$C V A_{i}=s_{i} \sum_{k=1}^{N} E E_{i}^{*}\left(t_{k}^{i}\right) \Delta t_{k}^{i} e^{-s_{i} t_{k}^{i} / L G D_{i}}$.

A bázeli szabályozással összhangban feltételezzük, hogy a hitelértékelési kiigazítás fedezésére hitelmulasztási ügyletet köthetünk. Ha a fedezet lejárata $\hat{T}^{j}$, akkor az értékét $0=t_{0}^{j}<t_{1}^{j}<\ldots<t_{N^{\prime}}^{j}=\hat{T}^{j}$ intervallumfelosztás mellett Pykhtin [2012] alapján a következő formában adhatjuk meg:

$C D S_{j}=B_{j}\left(s_{j}-s_{j}^{\text {contr }}\right) \sum_{k=1}^{N^{\prime}} D F\left(t_{k}^{j}\right) \Delta t_{k}^{j} e^{-s_{j} t_{k}^{j} / L G D j}$,

ahol $s_{j}^{\text {contr }}$ jelöli a szerződéskötéskor megállapított fix hitelfelárat.

A jelenleg hatályban lévő CVA-tőkeszabályozás csakis a partnerre szóló hitelmulasztási ügyleteket fogadja el, azaz a fenti CDS csak akkor elfogadható fedezet, ha az $i=j$ a fenti két egyenletben. Mivel az új javaslat enyhít ezen a szabályozáson, és nem tökéletes, proxy fedezeteket is elfogad, ezért mi külön indexet használunk a partnerre, illetve a referenciafedezet nevére. Egy partnert többféle eszközzel is fedezhetünk, így jelölje $C D S^{\text {portfólió }}(i)$ az $i$-edik fedezésére használt hitelmulasztási ügyletek portfóliójának értékét. Azaz ha Hedge(i) az i-edik partner fedezésére használt nevek indexei, akkor:

$\operatorname{CDS}^{\text {portfólió }}(i)=\sum_{j \in \text { Hedge(i) }} \operatorname{CDS}_{j}$.

A hitelértékelési kiigazítás a kockázatmentes árból levont mennyiség, tehát növekedése veszteséget jelent a félnek. ${ }^{7}$ Így a fedezett CVA rendelkezik azzal a tulajdonsággal, hogy megváltozását a fedező a CDS-portfólió megváltozásával ellensúlyozza. A tőketartalék meghatározásakor a fenti derivatívákból és a CVA-ból álló teljes portfólió összes partnerre aggregált értékeire vagyunk kíváncsiak. Tehát a szabályozói tőkét a

$\triangle C V A_{i}-\Delta C D S^{\text {portfólió }}(i)$

mennyiség összes partnerre vett értéke határozza meg.

Tökéletes fedezés esetén a portfólió megváltozása nulla:

$\triangle C V A_{i}-\Delta C D S^{\text {portfólió }}(i)=0$.

Ilyen esetben tehát a tőketartalékolási formulának elvárható tulajdonsága lenne, hogy egy ilyen portfólióhoz nulla tőkeszükségletet rendeljen.

Pykhtin [2012] rámutat, hogy a hatályos Bázel-III. szabályozásban szereplő standard képlet az így felírt portfólió megváltozásának elsőrendü közelítése egy egyfaktoros modell mellett. Kövessük most ezt az elemzést, és írjuk fel az elsőrendü közelítést, azonban engedjük meg a proxy fedezeteket a modellben!

Az elsőrendü közelítést alkalmazva a portfólió megváltozása a következő lesz:

$\Delta C V A_{i}^{\text {fedezett }}=A_{i} \Delta s_{i}-\sum_{j} \hat{B}_{j}^{i} \Delta s_{j}$

${ }^{7}$ A hitelértékelési kiigazítást szokás egy önálló, komplex derivatívaként is kezelni. 
ahol

$A_{i}=\frac{\partial C V A_{i}}{\partial s_{i}}=\sum_{k=1}^{N} E E_{i}^{*}\left(t_{k}^{i}\right) \Delta t_{k}^{i} e^{-s_{i} t_{k}^{i} / L G D_{i}}\left(1-s_{i} t_{k}^{i} / L G D_{i}\right)$,

és

$\hat{B}_{j}^{i}=\frac{\partial C D S_{j}^{i}}{\partial s_{j}}=B_{j}^{i} \sum_{k=1}^{N^{\prime}} D F\left(t_{k}^{j}\right) \Delta t_{k}^{j} e^{-s_{j} t_{k}^{j} / L G D_{j}}\left(1-s_{j} t_{k}^{j} / L G D_{j}+s_{j}^{\text {contr }} t_{k}^{j} / L G D_{j}\right)$.

A fenti egyenletben az eredeti $B_{j}$ névértéket $B_{j}^{i}$-re cseréltük, hogy jelezzük, hogy a $j$-edik partnerre vásárolt hitelmulasztási ügyletből mennyi is szolgált az $i$-edik partner fedezésére. Ebből adódóan $\hat{B}_{j}$ is $\hat{B}_{j}^{i}$-re változik. Jellemzően a fenti egyenletben szereplő szumma majdnem összes tagja nulla, hiszen egy partner fedezésére nem vesszük figyelembe az összes partnerre szóló fedezeti ügyleteket, de az általános felírás kedveért mégis ezt a jelölést alkalmazzuk. Tételezzük fel, hogy az $s$ hitelfelár az alábbi lognormális eloszlás szerint változik, ahogy azt Pykhtin [2012] is feltételezte:

$\Delta s_{i}=s_{i}^{0}\left(e^{-0,5 \sigma_{i}^{2} H+\sigma_{i} \sqrt{H} X_{i}}-1\right) \approx s_{i}^{0} \sigma_{i} \sqrt{H} X_{i}$,

és

$\Delta s_{j}^{(i)}=s_{j}^{0}\left(e^{-0,5 \sigma_{j}^{2} H+\sigma_{j} \sqrt{H} W_{i j}}-1\right) \approx s_{j}^{0} \sigma_{j} \sqrt{H} W_{i j}$,

ahol $X_{i}$ és $W_{i j}$ normális valószínűségi változók, $\sigma_{i}$ és $\sigma_{j}$ pedig a megfelelő volatilitások.

Vegyük észre, hogy ennél a pontnál már eltérünk Pykhtin [2012] munkájától, hiszen proxy fedezeteket is megengedünk a modellben. Tételezzük fel, hogy a hitelfelár mozgását meghatározó tényezők az alábbi faktormodell szerint változnak:

$W_{i j}=\xi X_{i}+\sqrt{1-\xi^{2}} V_{j}$,

és

$X_{i}=\rho Z+\sqrt{1-\rho^{2}} Z_{i}$,

ahol $V_{j}, Z_{i}$ és $Z$ független standard normális változók. A fenti felírással összekötjük a partner és a fedezeti ügylet referencianeve hitelfelárainak mozgását. Értelemszerüen $i=j$ esetén $\xi=1$ kikötéssel élünk.

Ezt a (23) egyenletbe visszahelyettesítve és az összes partnerre aggregálva az alábbi egyenletet kapjuk:

$$
\begin{aligned}
\Delta C V A^{\text {fedezett }} & =\sum_{i} \Delta C V A_{i}^{\text {fedezett }}=\sum_{i}\left(A_{i} s_{i}^{0} \sigma_{i} \sqrt{H} X_{i}-\sum_{j} \hat{B}_{j}^{i} s_{j}^{0} \sigma_{j} \sqrt{H} W_{i j}\right)= \\
& =\sqrt{H}\left\{\sum_{i}\left[\left(A_{i} s_{i}^{0} \sigma_{i}-\sum_{j} \xi \hat{B}_{j}^{i} s_{j}^{0} \sigma_{j}\right) X_{i}\right]-\sum_{i} \sum_{j} \sqrt{1-\xi^{2}} \hat{B}_{j}^{i} s_{j}^{0} \sigma_{j} V_{j}\right\}=
\end{aligned}
$$




$$
\begin{aligned}
& =\sqrt{H}\left\{\rho\left[\sum_{i}\left(A_{i} s_{i}^{0} \sigma_{i}-\sum_{j} \xi \hat{B}_{j}^{i} s_{j}^{0} \sigma_{j}\right)\right] Z+\right. \\
& \left.+\sqrt{1-\rho^{2}} \sum_{i}\left[\left(A_{i} s_{i}^{0} \sigma_{i}-\sum_{j} \xi \hat{B}_{j}^{i} s_{j}^{0} \sigma_{j}\right) Z_{i}\right]-\sum_{i} \sum_{j} \sqrt{1-\xi^{2}} \hat{B}_{j}^{i} s_{j}^{0} \sigma_{j} V_{j}\right\} .
\end{aligned}
$$

Vegyük észre, hogy az így kapott egyenlet független, standard normális változók lineáris kombinációja. A szögletes zárójelen belül $\left(N+N_{\text {hedge }}+1\right)$ darab független normális valószínűségi változó szerepel. Ez alapján tehát a (30) egyenlet előáll a következő alakban:

$\triangle C V A^{\text {fedezett }}=\sqrt{H} \beta Y$,

ahol

$$
\begin{aligned}
\beta^{2}= & \left\{\rho^{2}\left[\sum_{i}\left(A_{i} s_{i}^{0} \sigma_{i}-\sum_{j} \xi \hat{B}_{j}^{i} s_{j}^{0} \sigma_{j}\right)\right]^{2}+\right. \\
& \left.+\left(1-\rho^{2}\right) \sum_{i}\left(A_{i} s_{i}^{0} \sigma_{i}-\sum_{j} \xi \hat{B}_{j}^{i} s_{j}^{0} \sigma_{j}\right)^{2}+\sum_{i} \sum_{j}\left(1-\xi^{2}\right)\left(\hat{B}_{j}^{i} s_{j}^{0} \sigma_{j}\right)^{2}\right\},
\end{aligned}
$$

és $Y$ egy standard normális valószínűségi változó.

A bázeli szabályozás - összhangban a nemfizetési kockázat módszertanával - egyéves periódus alatti veszteségekre határozza meg a tőkeszükségletet, így a fenti képletet át kell skáláznunk egy $1 / \sqrt{H}$ faktorral. Továbbá az új CVA-tőkeszabályozás igyekszik összehangolni a követelményeket az új kereskedési könyv szabályozási keretrendszerével, így kockáztatott érték (VaR) helyett várható veszteség $(E S)$ kockázati mértéket használ $\alpha=0,75$ százalékos szignifikanciaszint mellett.

Megmutatható, hogy egy $X \sim N(\mu, \sigma)$ normális eloszlású valószínűségi változó várható veszteség $(E S)$ mértéke az alábbiak szerint számolható:

$E S_{\alpha}(X)=\mu-\frac{\phi\left[\Phi^{-1}(\alpha)\right]}{1-\alpha} \sigma$.

Amiből az következik, hogy

$E S_{0,975}(\beta Y)=\frac{\phi\left[\Phi^{-1}(0,975)\right]}{0,025} \beta=2,34 \beta$.

Így definiálhatjuk az elsőrendü közelítéssel kapott, 97,5 százalékos szignifikanciaszint melletti CVA-tőkeszükségletet:

$$
\begin{aligned}
\widehat{C V A}^{\text {tóke }} & =2,34\left\{\rho^{2}\left[\sum_{i}\left(A_{i} s_{i}^{0} \sigma_{i}-\sum_{j} \xi \hat{B}_{j}^{i} s_{j}^{0} \sigma_{j}\right)\right]^{2}+\right. \\
& \left.+\left(1-\rho^{2}\right) \sum_{i}\left(A_{i} s_{i}^{0} \sigma_{i}-\sum_{j} \xi \hat{B}_{j}^{i} s_{j}^{0} \sigma_{j}\right)^{2}+\sum_{i} \sum_{j}\left(1-\xi^{2}\right)\left(\hat{B}_{j}^{i} s_{j}^{0} \sigma_{j}\right)^{2}\right\}^{\frac{1}{2}} .
\end{aligned}
$$


Az így kapott formula hasonló az előző fejezetben közölt, szabályozói tőkét meghatározó formula $K_{\text {spread }}$ komponensével, azonban láthatjuk, hogy azzal nem teljes mértékben egyezik meg. Az eltérések föképpen a szabályozói standardizálásból és a bázeli formula konzervativizmusából adódnak, ahogy arra Pykhtin [2012] is rámutatott.

A standardizálás legszembetűnőbben a korrelációs és a volatilitásparamétereket érinti. A $\rho$ paraméter a bázeli formulában 0,5 értéket vesz fel, míg a fedezetekhez tartozó hitelfeláraknak a referencianév felárával való korrelációja ( $\xi$ ) az 1. táblázat alapján változik. Ahogy arra már Pykhtin [2012] is rámutatott, a standardizált formula esetében a kezdeti felár és a korrelációs paraméter együtt egy standard szabályozói súlyra cserélődik. A standardizált súlyok az új alap CVA-módszerben megváltoztak, és a 2,34-os szorzót is magukban foglalják. Új értéküket a 2. táblázat tartalmazza.

\section{2. táblázat}

Kockázati súlyok (százalék)

Szektor

Befektetésre Befektetésre nem ajánlott (IG) ajánlott (NIG)

\begin{tabular}{lrr}
\hline Államok, központi bankok, multilaterális fejlesztési bankok & 8,8 & 20,4 \\
Pénzügyi, ideértve kormányzat által garantált pénzügyi & 10,2 & 17,3 \\
$\begin{array}{l}\text { Alapanyagok, energia, ipar, mezőgazdaság, gyártás, bányászat, } \\
\text { Fogyasztási cikkek és szolgáltatások, szállítás és tárolás, }\end{array}$ & 7,1 & 13,0 \\
$\begin{array}{l}\text { adminisztratív és ügyfélszolgálati tevékenységek } \\
\text { Technológia és távközlés }\end{array}$ & 5,1 & 14,4 \\
$\begin{array}{l}\text { Egészségügy, önkormányzat, kormányzat által garantált nem } \\
\text { pénzügyi, oktatás, közszolgálat, müszaki tevékenységek }\end{array}$ & 4,1 & 13,0 \\
Indexek & 4,1 & 8,7 \\
\hline
\end{tabular}

A (35) egyenletben szereplő CVA-érzékenységet a szabályozás az alábbi egyenlőtlenséggel becsüli felül:

$$
\begin{aligned}
A_{i} & =\sum_{k=0}^{N} E E_{i}^{*}\left(t_{k}^{i}\right) \Delta t_{k}^{i} e^{-s_{i} t_{k} / L G D_{i}}\left(1-s_{i} t_{k}^{i} / L G D_{i}\right) \leq \sum_{k=0}^{N} E E_{i}^{*}\left(t_{k}^{i}\right) \Delta t_{k}= \\
& =M_{i} 1 / H \sum_{t_{k}<H} E E_{i}^{*}\left(t_{k}\right) \Delta t_{k}^{i} \leq M_{i} 1 / H \sum_{t_{k}<H} E E_{i}\left(t_{k}\right) \Delta t_{k}^{i}=M_{i} E P E_{i}=M_{i} \frac{E A D_{i}}{\alpha} .
\end{aligned}
$$

Az első egyenlőtlenségnél elhagytuk az $\left(1-s_{i} t_{k}^{i} / L G D_{i}\right)$ egynél kisebb tényezőt. A (36) „jobb oldalán” lévő egyenletet úgy kaptuk, hogy az effektív lejárat képletében megfeleltettük egymásnak a valódi és az effektív kitettségi profilt. Végül a diszkontált profilt a valódival becsüljük felül, és Pykhtin [2012]-t követve eltekintünk a kockázatsemleges és a valódi mérték alatt számolt várható kitettségi profil különbségétől.

A másik oldalon, Pykhtin [2012] megadja a fedezet közelítésének módját is. Ha feltételezzük, hogy $s_{j}=s_{j}^{\text {contr }}$, akkor:

$$
\hat{B}_{j}^{i}=B_{j}^{i} \sum_{k=0}^{N^{\prime}} D F\left(t_{k}^{j}\right) \Delta t_{k}^{j} e^{-s_{j} t_{k}^{j} / L G D_{j}} \leq \hat{T}_{j} B_{j}^{i} \frac{1}{\hat{T}_{j}} \sum_{k=0}^{N^{\prime}} D F\left(t_{k}^{j}\right) \Delta t_{k}^{j} \approx \hat{T}_{j} B_{j}^{i} \frac{1}{\hat{T}_{j}} \int_{0}^{\hat{T}_{j}} D F(t) d t .
$$


Tehát az (37) egyenletben megjelenik a lejárat és a diszkontált névérték szorzata, amit még a bázeli formula tovább egyszerüsít, mivel egy 5 százalékos szinten konstans hozamgörbét tételez fel. Ezzel az átalakítással eljutottunk a CVA-tőketartalék szabályozói formulájához.

\section{Numerikus eredmények}

Ebben a fejezetben numerikus példákon keresztül vizsgáljuk tovább az új módszert. Összehasonlítjuk a standard és az alap CVA-formulák eredményét különböző feltételek mellett. Hasonlóan rámutatunk az elméleti modell és a szabályozói formula közelítések által okozott eltéréseire.

Először a $\rho$ paraméter hatását vizsgáljuk egy fedezetlen portfólión. Példánkban 100 partnert tételezünk fel, miközben Pykhtin [2012] munkáját követve mindegyikhez egységnyi szinten konstans kitettségi profilt rendelünk. Az egyes ügyletek lejáratát az egy és öt év közötti intervallumból egyenletes eloszlással választjuk. Célunk, hogy összehasonlítsuk az alap CVA-módszer mögött levezetett egyenlet (35) által adott tőkeszükségletet és a szabályozói formulából kapott értéket.

A számítást három különböző minőségű portfólión végezzük el. Mindhárom esetben a $[-1,1]$ intervallumon futtatjuk a $\rho$ paramétert. Minden számoláskor 100000 szimulációt végzünk, ahol először a partnerek hitelminősítését, valamint szektorbeosztását határoztuk meg, majd a hitelfelár-volatilitásukat. A szektorokat a 2. táblázat 2. és 6. sora közötti értékek közül, míg a volatilitásparamétereket $P y k h t i n$ [2012] munkájához hasonlóan a $[0,2,0,4]$ intervallumból egyenletes eloszlás szerint választjuk. A három eset a hitelminősítések tekintetében különbözik egymástól. Az első esetben $[A A, A, B B B, B B, B, C C C]$ partnereket szimulálunk. A második esettel egy jó minőségü portfóliót illusztrálunk, így $[A A, A, B B B, \mathrm{BB}]$ minősítésü partnereket tételeztünk fel. Az utolsó esetben a $[B B B, B B, B, C C C]$ értékekből választva egy rosszabb minőségü portfóliót szemléltetünk. A kezdeti hitelfelárszintek ezen paraméterek alapján már adódnak, hiszen a (11) és a (35) egyenletek alapján $R W_{i}=2,34 s_{i}^{0} \sigma_{i}$. Az így kapott portfóliót futtatjuk mindkét módszertan mellett.

Az eredményeket az 1-3. ábrán közöljük. Minden ábra két részből áll. A felső részen $\rho$ különböző értékei mellett az új alap- és a Bázel-III. szabályozás standardizált módszereinek analitikus közelítésével számított tőkeszükséglet értékét adjuk meg. Ezekhez az „Alap analitikus” és a „Standard analitikus” neveket rendeltük a jelmagyarázatban. Ezzel párhuzamosan kiszámoltuk a szabályozói formulák által elő́rt tőketartalék nagyságát is. Az így kapott eredményeket a „Bázel alap” és a „Bázel standard” egyenes vonalak reprezentálják. ${ }^{8}$ A szabályozói tőkeszükséglet nem érzékeny a $\rho$ változására, hiszen a bázeli formulában a $\rho=0,5$ választással éltek a BCBS döntéshozói.

\footnotetext{
${ }^{8}$ A „Bázel alap” csak a hitelfelár-kockázat elleni tőkésítés, azaz a $K_{\text {spread }}$ tag. A teljes tőkenagyság jelen példában ennek pontosan a másfélszerese.
} 


\section{1. ábra}

A korreláció hatása átlagos portfólió esetén

\section{Töke}
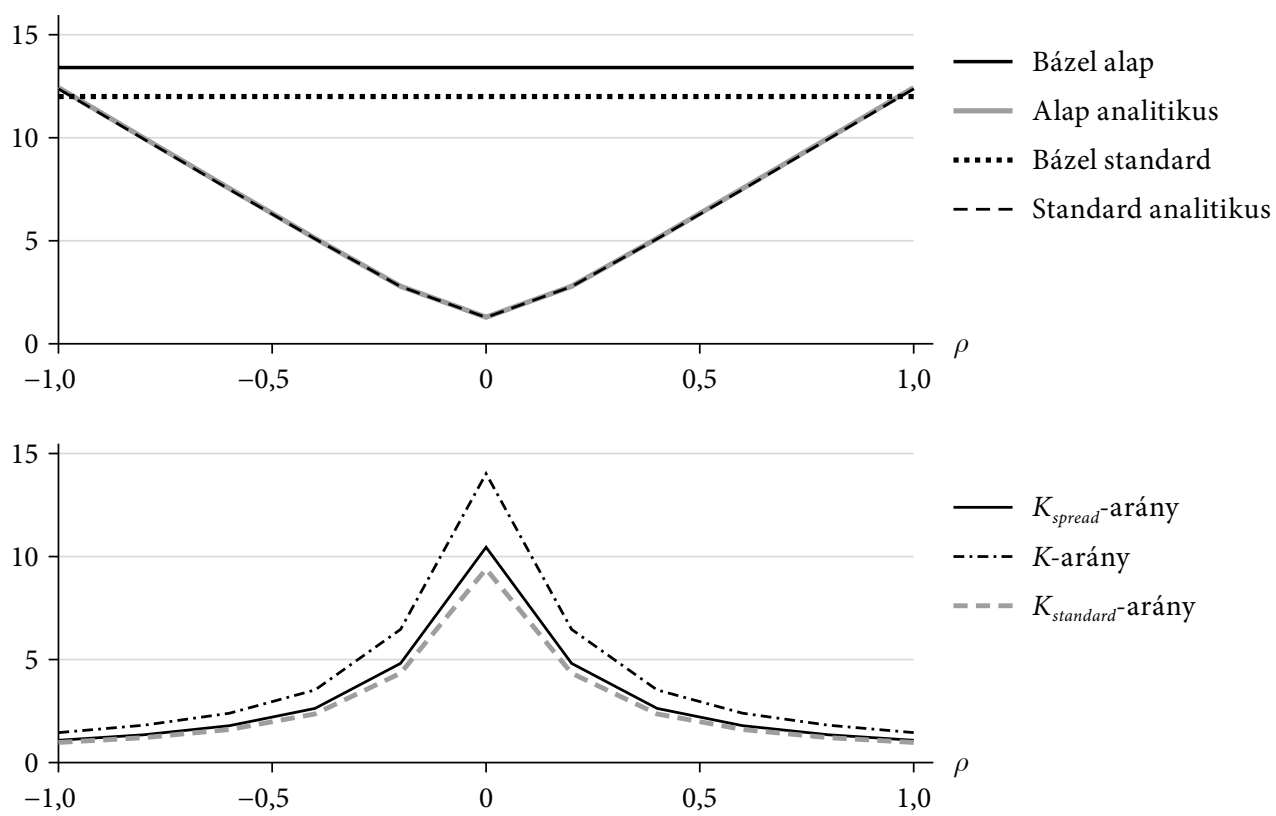

\section{2. ábra}

A korreláció hatása jó minőségű portfólió esetén
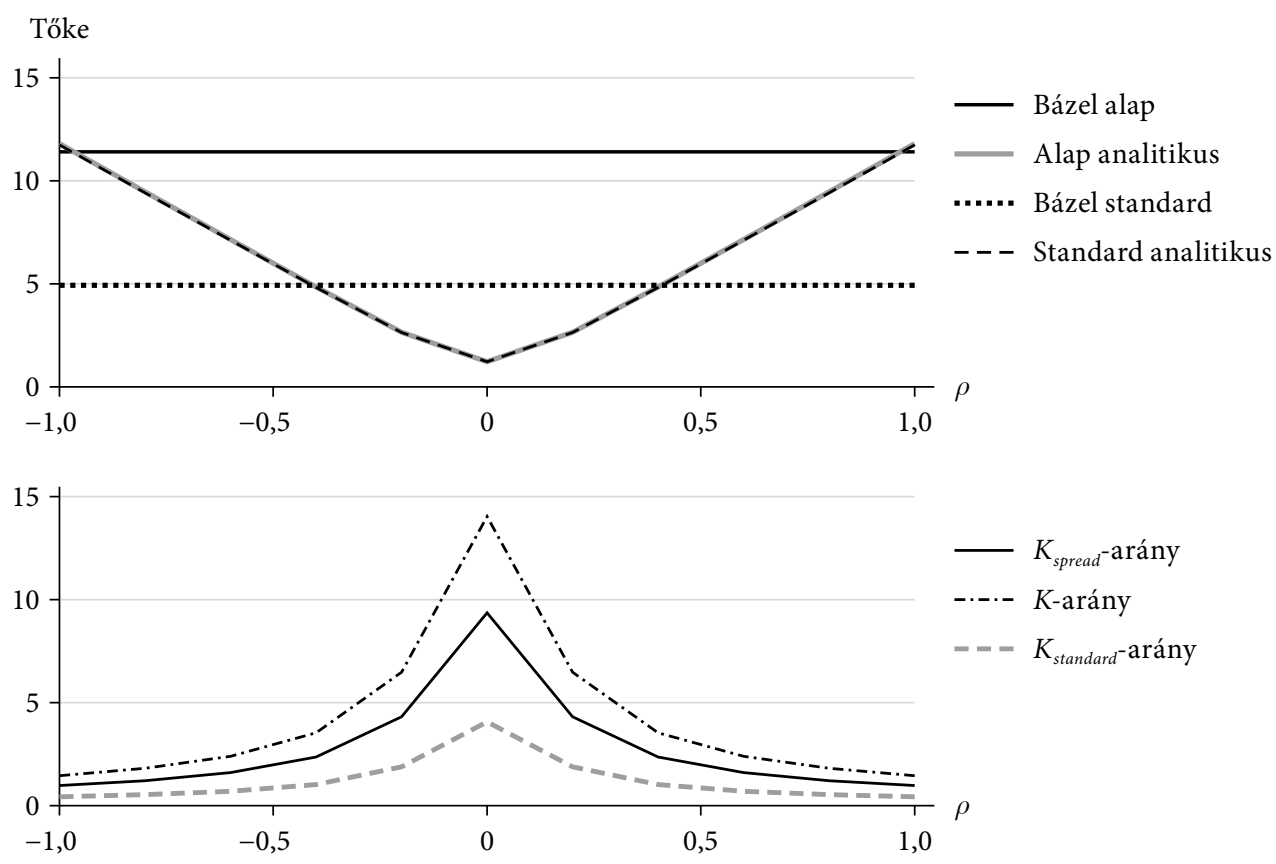
3. ábra

A korreláció hatása rossz minőségű portfólió esetén

Tőke
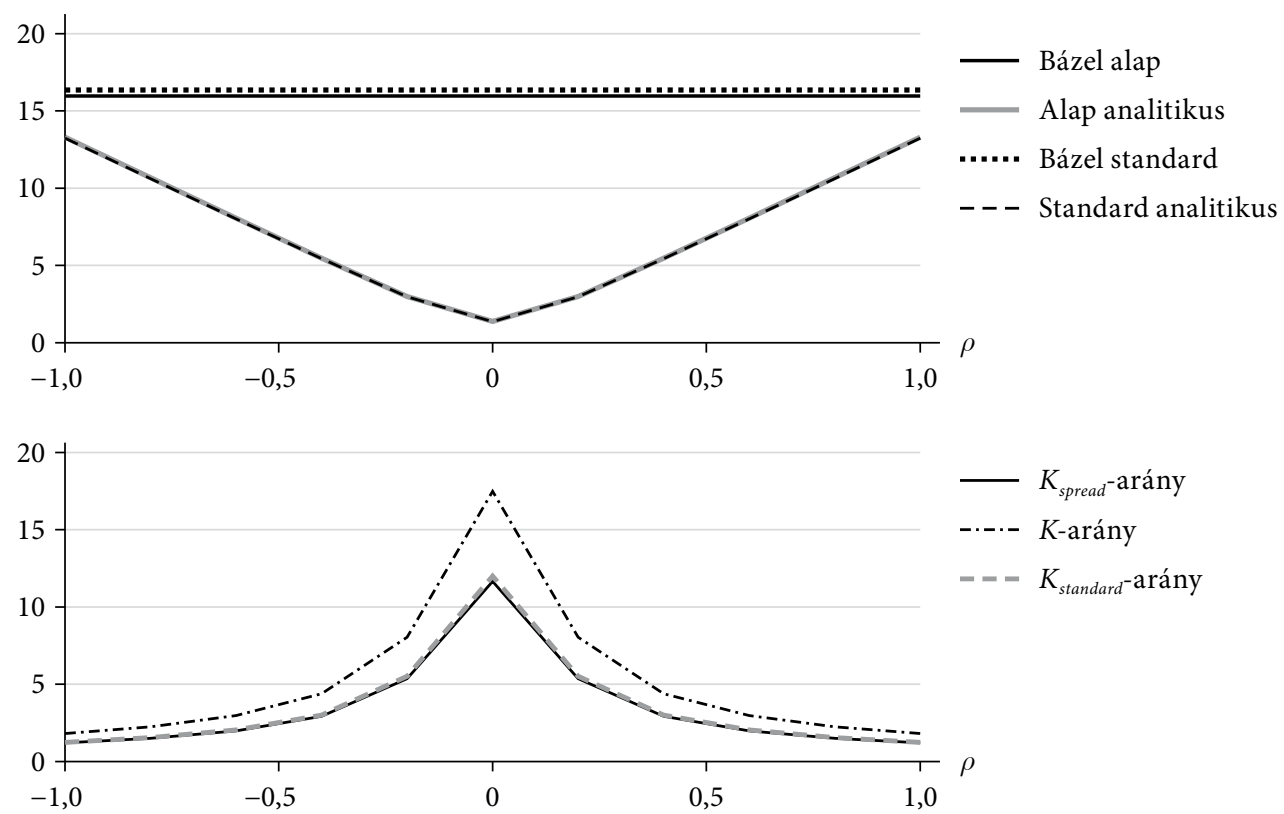

A tőketartalékok szintjei mellett érdemes a modellhez viszonyított konzervativitásukat is elemezni, ezért megvizsgáltuk a szabályozói formula és a modell által adott szükséges tőkeszintek hányadosait. Az így kapott eredményeket az ábrák alsó felében mutatjuk be. A $K_{\text {spread }}$-arány mutatja a hitelfelár mozgásából adódó kockázatra számolt szabályozói és analitikus közelítés arányát. A $K$-arány számítása a $K_{\text {spread }}{ }^{-}$ arányhoz hasonló, de figyelembe vettük az alap CVA-módszer teljes tőkeszükségletét, amelyet a (10) egyenlet alapján számoltunk. Végül a $K_{\text {standard }}$-arány jelenti a jelenlegi módszer alapján vett hányadost.

Mindhárom portfólió esetében, ha $\rho=0$, a valódi tőkeszükséglet minimális, és a szabályozói formula fölülbecslése maximális. Ilyen helyzetben ugyanis a portfóliót semmilyen közös faktor nem vezérli, így jellemzően az eloszlás farkában a portfóliószintü veszteségek kisebbek lesznek, hiszen az egyes partnerekhez rendelt veszteségeket gyakran ellensúlyozzák nyereségek, így azok kioltják egymást. Az ábrákon az is jól kivehető, hogy a két módszer analitikus közelítésével kapott eredmények a fedezetlen portfóliókra szinte egybeesnek. Ez a korábbi levezetés tükrében nem meglepö, hiszen láthattuk, hogy az új formula fóképpen a fedezeti ügyletek kezelésében tér el elődjétől. A szabályozói egyenlet legjobban a vizsgált intervallum szélein becsül alul. Ilyen esetben ugyanis távol kerülünk a szabályozói $\rho=0,5$ paramétertől, és a formula jellemzően már nem képes az abszolút értékben szélsőségesen nagy korrelációval járó magasabb veszteségeket kezelni.

Az átlagos portfólió esetében a hitelfelár mozgásából adódó veszteség elleni szabályozói tőkeszükséglet szigorít a Bázel-III. követelményein, mivel már a Bázel alap 
tőkeszükséglet is magasabb értéket vesz fel a korábbinál. Figyelembe véve a profil változásának a kockázatát is, a tényleges tőkekövetelmény még magasabb lesz. A $K_{\text {standard }}{ }^{-}$ arány és a $K$-arány összehasonlításával óvatosnak kell lennünk. A $K_{\text {standard }}$-arány tisztán a hitelfelár változásából adódó veszteségeket mutatja, míg a $K$-arány esetén helyesebb lenne a nevezőben a profil változásának hatását is szerepeltetni. Másrészt azonban a szabályozói formula sem a profil változásának kockázatát számszerűsíti, hanem a hitelfelár egyenletét használja fel újra. Így egy új szemléletmóddal az alap CVA-tökeszükségletet a jelen helyzetben úgy is tekinthetjük, mintha a hitelfelár mozgását másfélszeresen tőkésítené. Ezért a $K_{\text {standard }}$-arány és a $K$-arány összehasonlításnak egy ilyen alternatív megközelítés mellett van értelme: az 1. ábrán láthatjuk, hogy az új módszer jelentősen magasabb arányt rendel a portfólióhoz tetszőleges $\rho$ esetén, ami azt jelenti, hogy a hitelfelár mozgását sokkal szigorúbban tőkésíti.

Az eredmények részben hasonlók, ha megváltoztatjuk a partnerek hitelminősítését, de érdemes rámutatni két fontos eltérésre. Egyrészt a jobb portfóliót (2. ábra) tekintve az új módszer sokkal szigorúbb, mint az átlagos portfólió esetében. Ilyenkor ugyanis már a Bázel alap szintje is többszöröse a Bázel standard tőkeszükségletének. Ugyan láthatjuk, hogy az előző formula az intervallum nagy részén alulbecsült, de ekkora mértékủ szigorításra nehéz magyarázatot találni. Másrészt a rossz minőségü portfólió (3. ábra) esetén az abszolút tőkeszükséglet és az arányszámok magasabbak, de a korábbi megfigyeléseink továbbra is igazak. Magasabb arányszám jellemzően konzervatívabb standardizálást jelent, hiszen ilyen esetben a szabályozói formula jobban eltér a modell által előjelzett értéktől.

\section{3. táblázat}

Kockázati súlyok az iparági felmérés keretében (százalék)

\begin{tabular}{|c|c|c|c|c|}
\hline \multirow[t]{2}{*}{ Szektor } & \multicolumn{2}{|c|}{ 1. változat } & \multicolumn{2}{|c|}{ 2. változat } \\
\hline & $\begin{array}{l}\text { befektetésre } \\
\text { ajánlott (IG) }\end{array}$ & $\begin{array}{l}\text { befektetésre } \\
\text { nem ajánlott } \\
\text { (NIG) }\end{array}$ & $\begin{array}{l}\text { befektetésre } \\
\text { ajánlott (IG) }\end{array}$ & $\begin{array}{l}\text { befektetésre } \\
\text { nem ajánlott } \\
\text { (NIG) }\end{array}$ \\
\hline $\begin{array}{l}\text { Államok, központi bankok, } \\
\text { multilaterális fejlesztési bankok }\end{array}$ & 0,5 & 3,0 & 0,9 & 3,7 \\
\hline $\begin{array}{l}\text { Önkormányzat, kormányzat által } \\
\text { garantált nem pénzügyi, oktatás és } \\
\text { közszolgálat }\end{array}$ & 1,0 & 4,0 & 1,2 , & 4,0 \\
\hline $\begin{array}{l}\text { Pénzügyi, ideértve kormányzat által } \\
\text { garantált pénzügyi }\end{array}$ & 5,0 & 12,0 & 6,1 & 12,0 \\
\hline $\begin{array}{l}\text { Alapanyagok, energia, ipar, } \\
\text { mezőgazdaság, gyártás, bányászat }\end{array}$ & 3,0 & 7,0 & 3,7 & 7,0 \\
\hline $\begin{array}{l}\text { Fogyasztási cikkek és szolgáltatások, } \\
\text { szállítás és tárolás, adminisztratív és } \\
\text { ügyfélszolgálati tevékenységek }\end{array}$ & 3,0 & 8,5 & 3,7 & 8,5 \\
\hline Technológia és távközlés & 2,0 & 5,5 & 2,4 & 5,5 \\
\hline Egészségügy, műszaki tevékenységek & 1,5 & 5,5 & 1,8 & 5,0 \\
\hline
\end{tabular}




\section{4. ábra}

A korreláció hatása átlagos portfólió esetén, QIS-súlyokkal
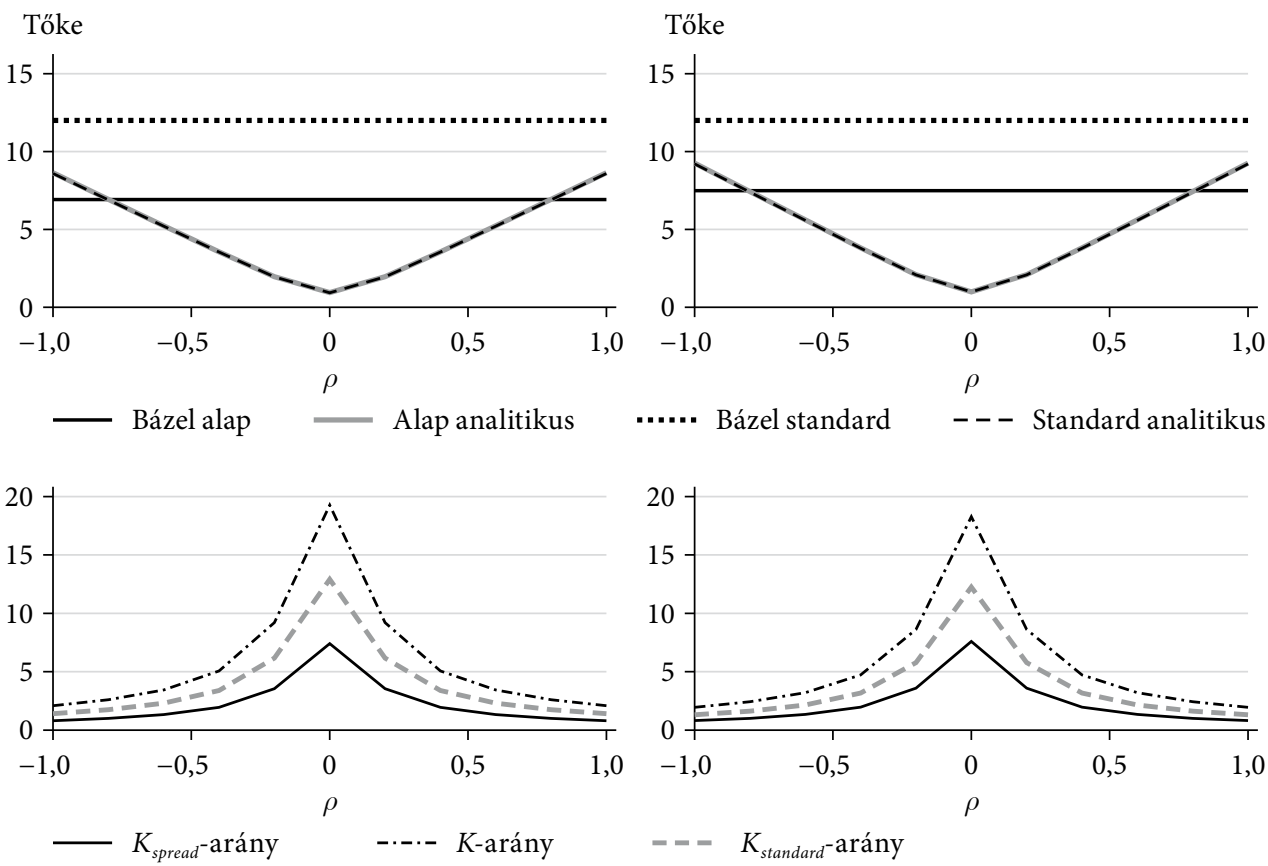

A Bázeli Bankfelügyeleti Bizottság 2016 februárjában egy iparági szintű gyakorlat keretében egy kissé módosított szabályozást adott ki. A módosítás nem érintette az alap CVA-módszertant, viszont a paramétereit újrakalibrálták. Így a kockázati súlyok is megváltoztak. Standard kvantitatív hatásvizsgálatának (QIS) instrukciójában a Bázeli Bankfelügyeleti Bizottság arra kérte a részt vevő bankokat, hogy végezzenek teszteket a saját portfóliójukon két különböző paraméterhalmazt is felhasználva. Az új kockázati súlyokat a 3. táblázatban közöljük.

A fent ismertetett elemzést az új kockázati súlyokkal is elvégezve valamelyest eltérö képet kapunk. A 4-6. ábra felső részén a legszembetűnőbb változás, hogy a szabályozói formula és az analitikus közelítés metszéspontjai alacsonyabbra kerültek. Ez azt mutatná, hogy a szabályozói formula kevésbé szélsőséges korreláció mellett is képes alulbecsülni a modell szerint elvárt tőkeszükségletet, azonban a másfélszeres szorzó alkalmazása után ez a lehetőség eltűnik. Továbbá megállapíthatjuk, hogy a tőkeszükséglet abszolút szintje mindhárom típusú portfólió esetében csökkent.

Fontos megjegyezni, hogy az előző ábrákkal való összehasonlításnál figyelembe kell vennünk, hogy időközben a portfólió is megváltozott. Ugyan a hitelminősítés és a hitelfelár-volatilitás ugyanaz, mint korábban, de a hitelfelárak kiinduló szintjei az $R W_{i}=2,34 s_{i}^{0} \sigma_{i}$ összefüggés miatt megváltoztak, hiszen új kockázati súlyokat használunk. A bázeli formula nem használja a hitelfelárakat, így bázeli szemüvegen keresztül a két portfólió megegyezik. Ezért az abszolút tőkeszükséglet nagyságának összehasonlítását megtehetjük, de a modell által adott eredmények eltéréseikor figyelembe kell vennünk a lehetséges portfólióhatásokat is. Ha az ábrák alsó 
5. ábra

A korreláció hatása jó minőségű portfólió esetén, QIS-súlyokkal

Tőke

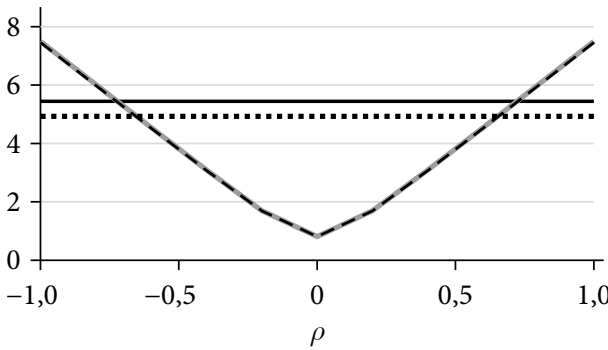

Bázel alap _ Alap analitikus

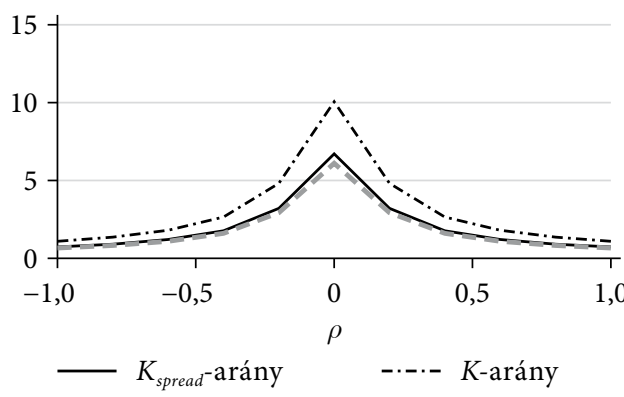

Tőke

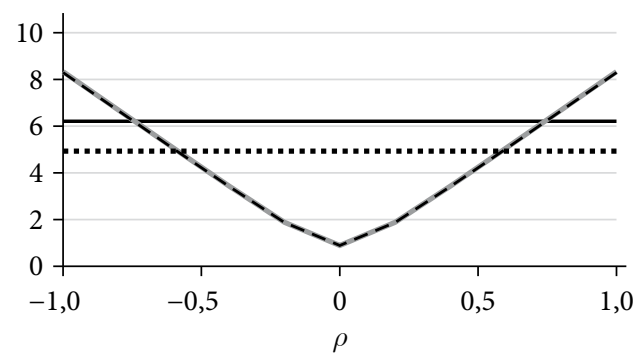

Bázel standard _ - - Standard analitikus

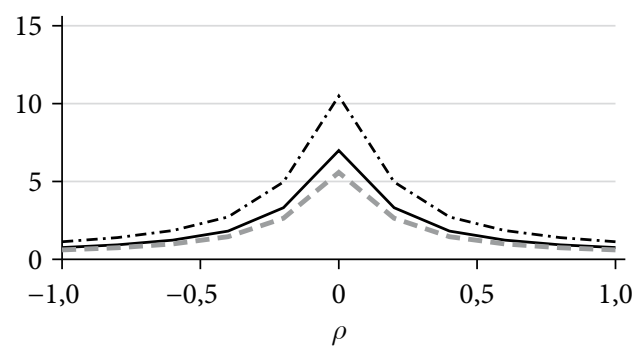

$-K_{\text {standard }}$-arány

\section{6. ábra}

A korreláció hatása rossz minőségű portfólió esetén, QIS-súlyokkal

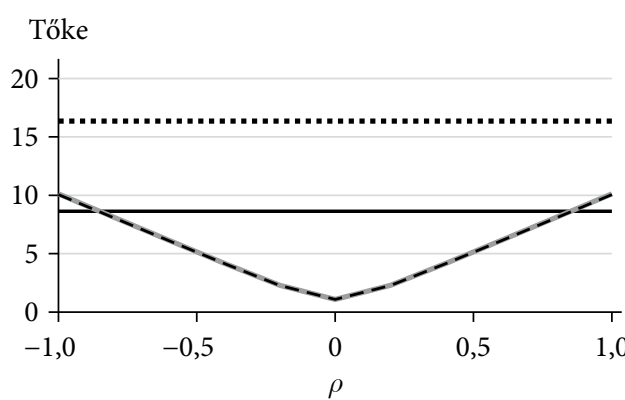

Bázel alap — Alap analitikus

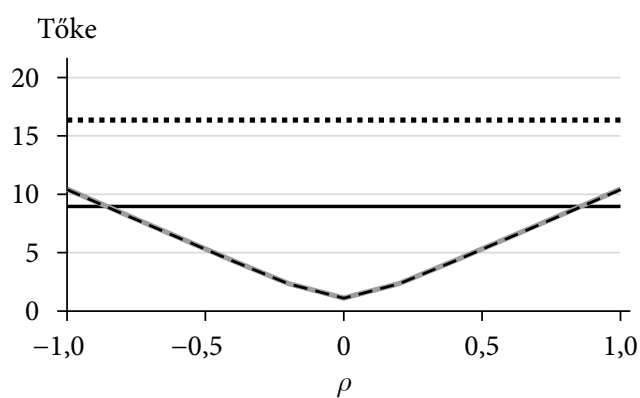

Bázel standard _ - - Standard analitikus
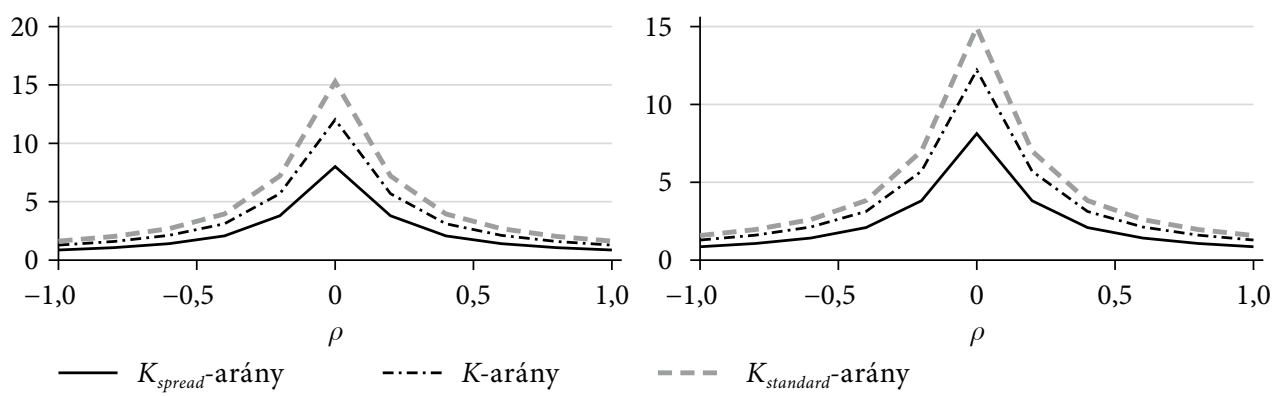

$-=-K_{\text {standard }}$-arány 
részére tekintünk, akkor láthatjuk, hogy a $K_{\text {spread }}$-arány vagy a $K$-arány már nem minden esetben a legmagasabb.

A fedezés hatásának teszteléséhez egy egyetlen partnerből álló portfóliót tételezünk fel, ahol minden egyes számításhoz 100000 szimulációt futtatunk. Célunk a tökéletes fedezéshez szükséges portfólió megtalálása, miközben megvizsgáljuk, hogy mekkora tőkeszükséglettel jár egy ilyen portfólió. Így azt feltételezzük, hogy a hitelértékelési kiigazítást számoló fél partnerére vásárolt fedezeti ügyletet - azaz mind az analitikus közelítésben, mind pedig a szabályozói formulában a $\xi=1$ értéket használhatjuk. Mivel a standardizált kockázati súlyok, a hitelfelár kiinduló értéke és annak volatilitása összekötik az analitikus közelítést és a bázeli formulát, ezért ezek értékeit nem választhatjuk meg egymástól függetlenül. A jelen példában két hitelminősítést [ $A A$ (IG), $B$ (NIG)] vizsgálunk alacsony (20 százalékos) és magas (40 százalékos) hitelfelár-volatilitást feltételezve.

$\mathrm{Az}$ analitikus közelítés (35) képletéből láthatjuk, hogy az $i=j$, és így a $\xi=1$ esetekben a fedezet tökéletes, ha $A_{i}=\hat{B}_{i}$. Ennek eléréséhez a fedezet lejáratát, valamint névértékét kell jól beállítanunk, figyelembe véve az eredeti ügylet lejáratát, valamint a diszkontált profil alakját. Hasonló témát vizsgál Berns [2016] is, amely a hatályos standardizált CVA-tökeformula esetén a nulla tőkekövetelményü és a tökéletesen fedezett portfólió eltérését elemzi. Berns [2016] alapján a számviteli CVA fedezéséhez egy $B=\frac{1}{M} \int_{0}^{M} E E(t) d t$ névértékủ hitelmulasztási ügyletet kell vásárolni, míg a standardizált CVA-szabályozás szerint egy nulla tőkekövetelményü portfólióhoz $B=E A D$ névértékü CDS-re van szükség. Ez alapján könnyen adódna, hogy az alap CVA-szabályozás szerint $B=E A D / \alpha$ mellett kapnánk nulla tökekövetelményt, feltéve, hogy a lejáratokat összeegyeztettük. Míg Berns [2016] közelítése bizonyos esetekben igaz, vegyük észre, hogy számos egyszerüsítése miatt nem ad tökéletes leírást, ugyanis figyelmen kívül hagyja a CDS-felár lábának a hitelfelárak mozgásából adódó értékmegváltozását, a hitelértékelési kiigazítást az effektív lejáratig vett integrálként írja fel, és megkülönböztetés nélkül használja a fedezeti ügylet diszkontált és a valódi névértékét. $\mathrm{Az}$ általunk korábban felírt modellkeret mellett pontosabb elemzést tudunk elvégezni, ezért folytassuk a numerikus eredmények bemutatásával.

Példánkban a konstans kitettségi profil szintjét, az eredeti ügylet lejáratát és a fedezet névértékét is egységnyinek választottuk, és így a fedezet lejárata az egyetlen változó paraméter. ${ }^{9}$ Igy a tökéletes fedezetet meghatározó lejáratot keressük, miközben a bázeli tőkeszükségletet is számoljuk.

Eredményeinket a 7. és a 8. ábrán szemléltetjük: a lejáratok függvényében mutatjuk a tőkeszükséglet nagyságát. Első ránézésre a vízszintes tengelymetszetek eltérése a legszembetünőbb. Láthatjuk, hogy a bázeli formula szempontjából tökéletesen fedezett portfólió valójában nem kockázatmentes, és hasonlóan a ténylegesen

\footnotetext{
${ }^{9}$ Nem szabad elfelejtenünk, hogy egy fedezési céllal kötött CDS-ügylet újabb kitettséget generálhat. Ez megváltoztathatja a portfóliószintű hitelértékelési kiigazítás értékét, így a tökéletesen fedezett CVA nem minden esetben elérhető. Egységnyi kitettségi profil választásával ezt a kapcsolatot figyelmen kívül hagyjuk a numerikus példában. Ez az egyszerüsítő feltételezés azonban valós piaci helyzetben is elképzelhető, hiszen ugyanilyen eredményhez jutunk, ha a fedezeti ügyleteket klíringházon keresztül kötjük.
} 
fedezett portfólió tőkeszükséglete nem nulla. Ez a megfigyelés a jelenleg hatályban lévő standardizált formulára is igaz, ezért az új módszer célja volt, hogy jobban összehangolja a számviteli és a szabályozói hitelértékelési kiigazítást, és javítsa a fedezeti ügyletek felismerését. Az $\alpha$ tényezővel történő osztás a (13) egyenletben segített ezen, azonban ahogy az ábrán láthatjuk, a tökéletes egyezés továbbra sem áll fenn.

7. ábra

Befektetésre ajánlott portfólió

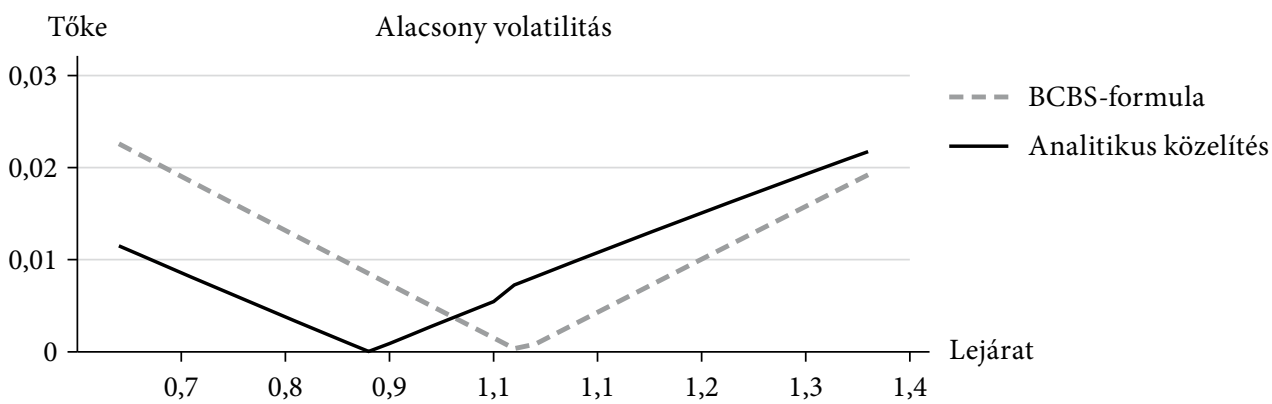

Tőke Magas volatilitás

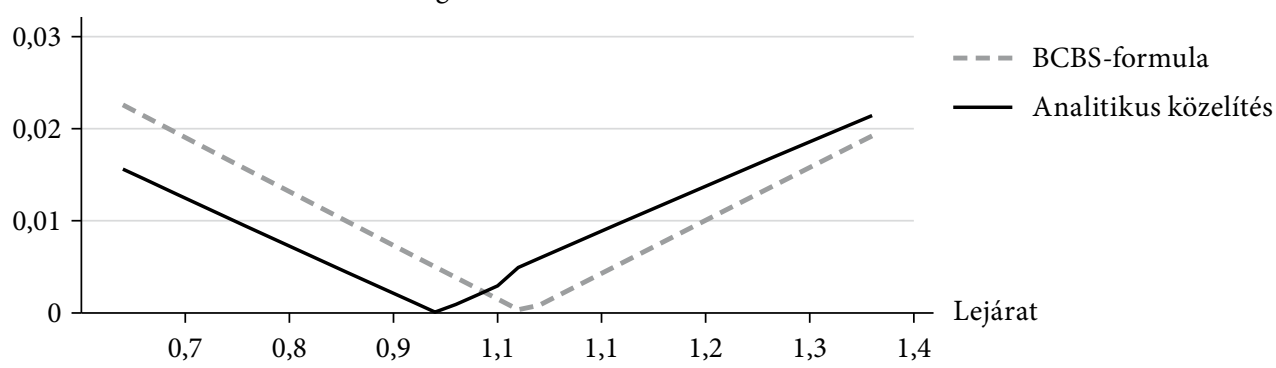

Jellemzően a fedezeti ügylet lejáratának rövidítésével érhetünk el tökéletes fedezetet a (35) egyenlet alapján, amit elsősorban a CDS-felár lábával magyarázhatunk. A hitelfelár változása ugyanis a CDS fix és változó lábára is hatással van. Növekedő felárak mellett a csőd esetén fizető láb többet ér. Ezzel szemben a csődig tartó felárfizetés kevesebbet fog érni, hiszen a túlélés valószínűsége csökken. Így a CDS értéke két okból is változik: jobban ellensúlyozza a CVA változását, és csökkenti a tökéletes fedezethez szükséges lejáratot. Kisebb hitelfelár-volatilitás mellett nagyobb kezdeti felárról indulunk, mivel $R W_{i}=2,34 s_{i}^{0} \sigma_{i}$. Így az $s_{i}^{\text {contr }}$ tag szerepe a (25) egyenletben is nagyobb lesz, ezért láthatjuk, hogy a kisebb volatilitás mellett a fedezet lejárata tovább csökkenthető.

Másrészt a fenti egyszerü portfólió mellett az alap CVA-formulát is leegyszerüsíthetjük, hogy megtaláljuk a tökéletes fedezetet. Hiszen amíg

$S_{c}=S_{h}^{S N}$,

azaz

$\frac{R W_{b(c)}}{\alpha} M_{n s} E A D_{n s}=R W_{b(c)} M_{h}^{S N} B_{h}^{S N}$ 
8. ábra

A tőkeszükséglet nagysága, befektetésre nem ajánlott portfólió

Töke

Alacsony volatilitás

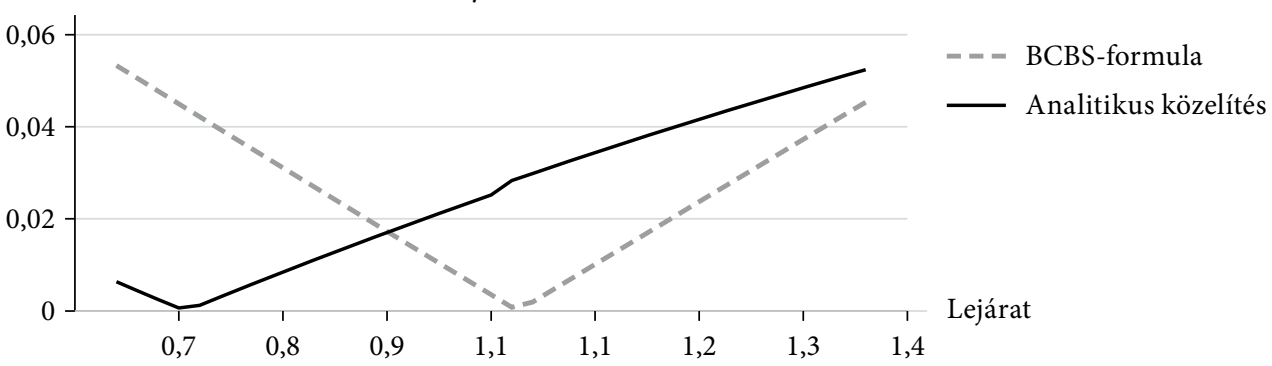

Tőke Magas volatilitás

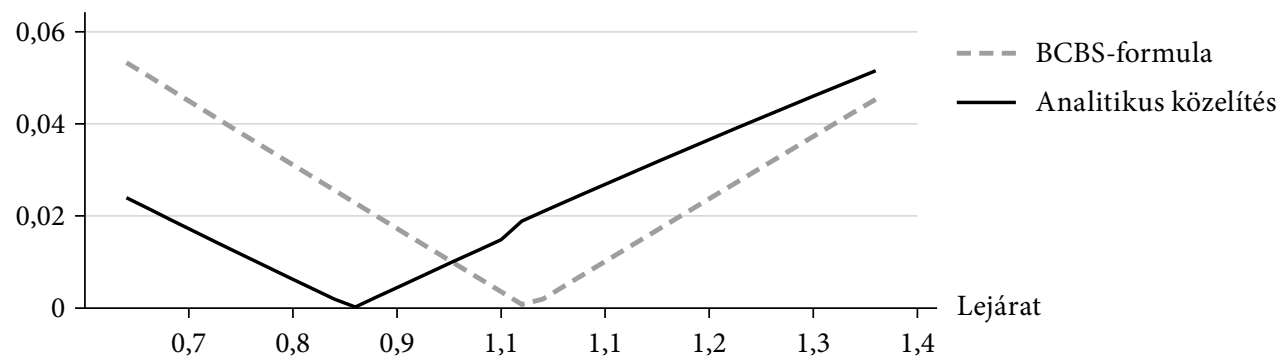

teljesül, addig a tőkeszükséglet értéke nulla lesz. Egyszerüsítve a fenti egyenletet és behelyettesítve az eredeti ügylet effektív lejáratát és a fedezeti ügylet diszkontált névértékét, az alábbi egyenlőséget kapjuk:

$E E P E_{n s}=M_{h}^{S N} B^{i} \frac{1}{M^{S N}} \int_{0}^{M^{S N}} D F(t) d t=B^{i} \int_{0}^{M^{S N}} D F(t) d t$

A példában egységnyi névértéket és $E E P E$-t feltételeztünk, így adódik, hogy a jellemzően egységnél kisebb diszkontfaktorokat valamivel egy éven túl kell integrálni, hogy teljesüljön a fenti feltétel. Ez látszik a 7. és a 8. ábrán is, hiszen minden esetben valamivel egy év feletti lejáratú fedezet esetén kapjuk meg a nulla tőkeszükségletet. Érdekes látni, hogy az ábrázolt szabályozói tőkeszükséglet ugyan függ a portfólió hitelminőségétől, annak minimuma ettől független. Az analitikus közelítés és a szabályozói formula eltérései az érzékenységi paraméterek előzőkben megadott átalakításaiból adódnak.

A fentiek alapján láthatjuk, hogy ha nagyon magas volatilitást tételezünk fel, akkor az analitikus közelítés minimuma közelebb kerül a szabályozóihoz. Ebből azonban adódik egy újabb, az ábrákon is jól látható megfigyelés: a példánkhoz hasonló esetekben a szabályozói formula bizonyos intervallumokon alulbecsülheti a tényleges tökeszükségletet. Láthatjuk, hogy az alulbecslés a szabályozói függvény meredek növekedése miatt csupán egy rövid intervallumon áll fenn, és a mértéke sem túl jelentős, ez azonban fontos észrevétel, hiszen rámutat a korábban közölt átalakítások mellékhatására.

A tökéletes fedezetre vonatkozó tesztünket a QIS-súlyok alapján is újrafuttattuk. $\mathrm{Az}$ eredményeket a 9. és a 10. ábrán szemléltetjük. Bár a tökéletesen fedezett és a 


\section{9. ábra}

Befektetésre ajánlott portfólió

1. változat

Tőke

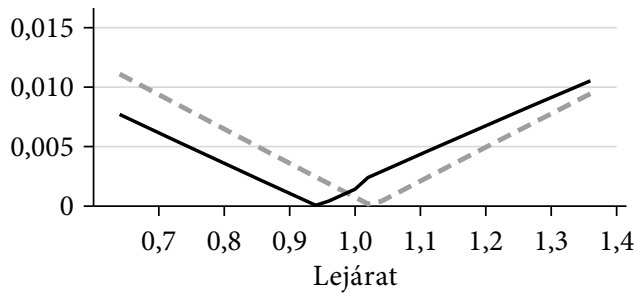

Lejárat

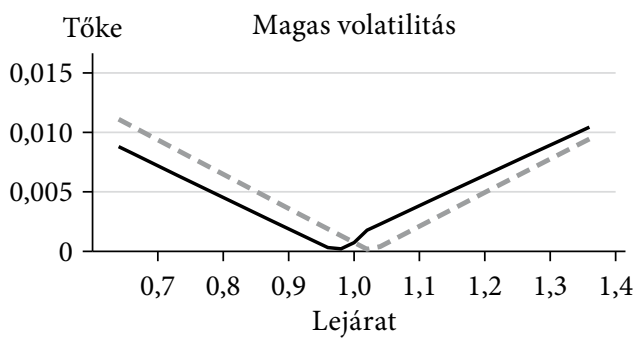

\section{2. változat}

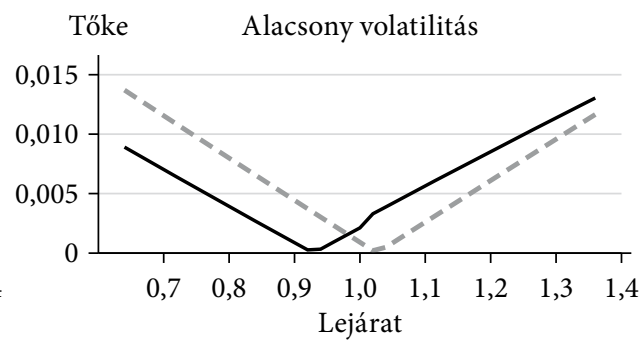

Tőke Magas volatilitás

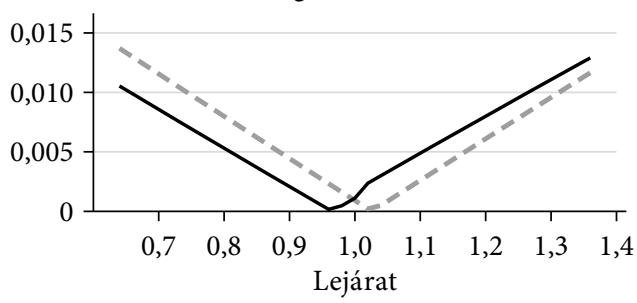

--- BCBS-formula —— Analitikus közelítés

\section{0. ábra}

Befektetésre nem ajánlott portfólió

1. változat

Tőke
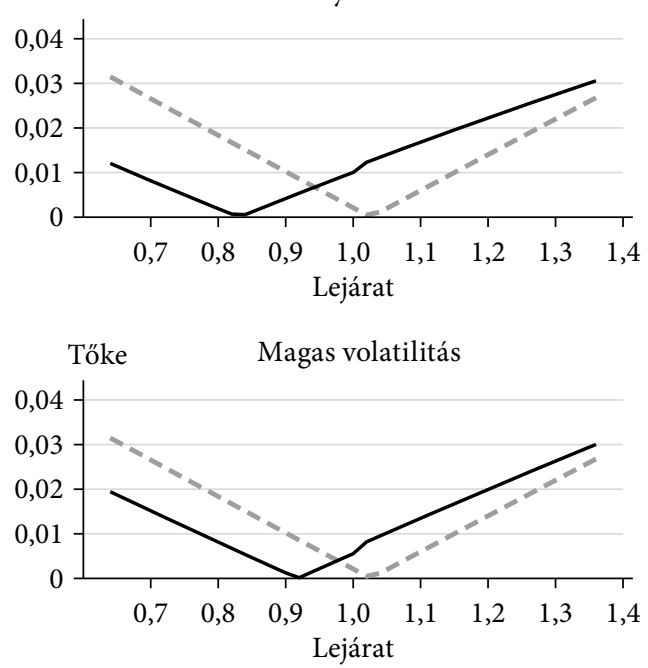

2. változat
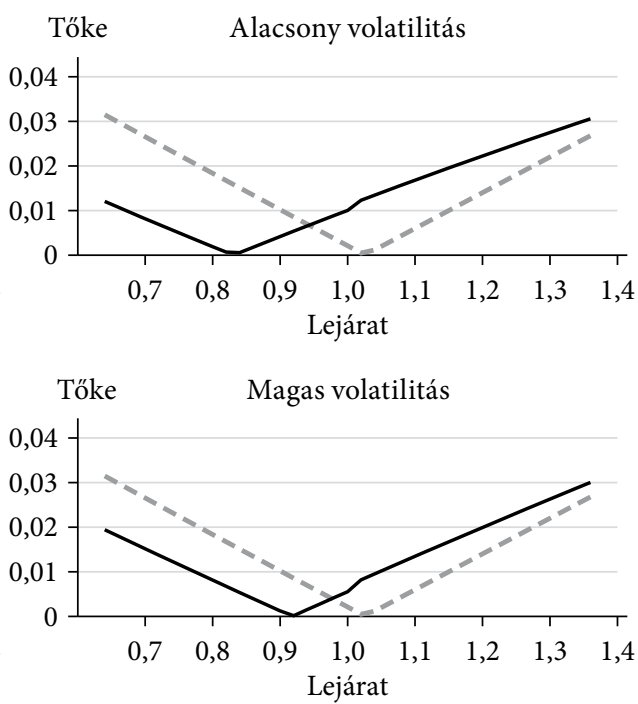

Analitikus közelítés 
nulla tőkeszükségletű portfóliók továbbra sem esnek egybe, a tesztportfóliónkon javulást láthatunk mindkét változat mellett. A két portfólió közeledésének az oka, hogy az új kockázati súlyok szintjei alacsonyabbak. Ilyen feltétel mellett a tesztportfóliónkhoz alacsonyabb kiinduló hitelfelárat rendelünk, ami a korábban leírtak miatt közelebb viszi a két portfóliót.

\section{Összegzés}

A bankok és a tőketartalékolás szabályozása az elmúlt évek egyik legfontosabb és legtöbbet elemzett pénzügyi témája lett. A gazdasági világválság után bevezetett új keretrendszer új időszak kezdetét jelenti. A szabályozás mértéke és formája azonban folyamatosan revízióra szorul, amelynek jó példája a hitelértékelési kiigazítás mozgásából adódó veszteségek elleni tőketartalékolás.

Mivel az új szabályozási javaslatok bankok ezreit is érinthetik, ezért érdemes azokat minél alaposabban elemezni. Ugyan a tényleges hatás elemzését a bankok aktuális portfólióján kell elvégezni, célszerű mindig elméleti szempontból is megvizsgálni az új javaslatokat. Alapos megértésük és tulajdonságaik elemzése elengedhetetlen a szabályozás javítása érdekében. Jelen tanulmány a hitelértékelési kiigazítás témakörére szorítkozva ehhez a feladathoz kívánt hozzájárulni.

A Bázeli Bankfelügyeleti Bizottság 2015 júliusában kiadott javaslata egy új CVAtőketartalékolási rendszert ajánl. Ebben a tanulmányban az új hitelértékelési kiigazítási szabályozásban leírt alap CVA-módszert vizsgáltuk meg. Elsőként bemutattuk a bázeli formula mögött meghúzódó matematikai modellt és az attól való szabályozói eltéréseket. Levezetésünk alapján látható, hogy az új szabályozói formula az egyes partnerekhez rendelt hitelértékelési kiigazításból és a hozzájuk tartozó fedezeti ügyletekből álló portfólió várható veszteség (ES) alapú kockázati mértéke. A modell dinamikáját a hitelfelárak változása adja, amelynek a hátterében egy speciális normális faktormodell áll. A levezetés magában foglalja a közvetlenül nem a partnerre vonatkozó, úgynevezett proxy fedezeteket is.

Az új formula néhány tulajdonságát és a jelenleg hatályos változatával való összehasonlítását numerikus példákon keresztül is illusztráltuk. Ennek során egy hipotetikus portfóliót fedezettel és a nélkül teszteltünk. Rámutattunk, hogy az eredetileg javasolt új kockázati súlyok indokolatlanul magas tőketartalékolást eredményeznek, miközben a módosított javaslatban már bizonyos szintü enyhítést láthatunk. A korreláció hatásának elemzésénél láthattuk, hogy a szabályozói formula felülbecslése a $\rho=0$ esetben a közös faktor hiánya miatti alacsony veszteségek mellett a legmagasabb. Ez a megfigyelés az eredeti kockázati súlyokkal számolt jobb minőségű portfólió esetében még inkább fennáll.

Numerikus szemléltetésünk második részében megmutattuk, hogy a szabályozói és a számviteli hitelértékelési kiigazítás teljes összeegyeztetése továbbra sem történik meg, így a két nézőpont szerint tökéletesen fedezett portfóliók is eltérnek egymástól. Mellékesen az is kiderült, hogy a szabályozói formula bizonyos intervallumokon alulbecsüli a tényleges tőkeszükségletet. Az általunk elvégzett elemzések mind a bankok kockázatkezelöi, mind a szabályozók számára is hasznos lehet. 


\section{Hivatkozások}

BCBS [2011]: Basel III: A global regulatory framework for more resilient banks and banking systems. Basel Committee on Banking Supervision, Bank for International Settlements, https://www.bis.org/publ/bcbs189.pdf.

BCBS [2015]: Review of the credit valuation adjustment risk framework. Basel Committee on Banking Supervision, Bank for International Settlements, https://www.bis.org/bcbs/ $\mathrm{publ} / \mathrm{d} 325$.pdf.

BCBS [2016a]: Minimum capital requirements for market risk. Basel Committee on Banking Supervision, Bank for International Settlements, http://www.bis.org/bcbs/publ/d352.pdf.

BCBS [2016b]: Reducing variation in credit risk-weighted assets - constraints on the use of internal model approaches. Basel Committee on Banking Supervision, Bank for International Settlements, https://www.bis.org/bcbs/publ/d362.pdf.

BCBS [2016c]: Frequently asked questions on the CVA QIS exercise. Basel Committee on Banking Supervision, Bank for International Settlements, https://www.bis.org/bcbs/qis/ faq_CVA_QIS.pdf.

BERNS, C. [2016]: Simultaneous hedging of regulatory and accounting CVA. Megjelent: Glai, K.-Grbac, Z.-Scherer, M.-Zagst, R. (szerk.): Innovations in Derivatives Markets Springer. 117-132. o. https://doi.org/10.1007/978-3-319-33446-2_6.

Brigo, D.-Morini, M.-Pallavicini, A. [2013]: Counterparty credit risk, collateral and funding: With pricing cases for all asset classes. John Wiley \& Sons, https://doi. org/10.1002\%2F9781118818589.

Carver, L. [2013]: Capital or P\&L. Deutsche Bank losses highlight CVA trade-off. Risk. net, október 31. https://www.risk.net/regulation/basel-committee/2295553/capital-or-pldeutsche-bank-losses-highlight-cva-trade.

Рукнтіл, M. [2012]: Model foundations of the Basel III standardised CVA charge. Risk, Vol. 25. No. 7. 60-66. o.

SHERIF, N. [2016]: Basel considered axing standardised approach to CVA calculation. Risk. net, november 14. http://www.risk.net/risk-management/2477114/basel-considered-axingstandardised-approach-cva-calculation.

Wood, D. [2016]: Crying wolf on CVA? Risk.net, március 30. http://www.risk.net/regulation/ basel-committee/2452746/crying-wolf-cva. 